\title{
Henryk Baranowski (1920-2011) jako twórca bibliografii lokalnych
}

STRESZCZEnIE: Henryk Baranowski wniósł znaczący wkład do rozwoju bibliografii lokalnej w Polsce. Spod jego pióra wyszły pionierskie na gruncie polskim retrospektywne bibliografie przedmiotowe Torunia, Wilna i Słupska. Zainicjował także bieżące bibliografie Elbląga i Grudziądza, które są kontynuowane po dzień dzisiejszy. Bibliografie opierał na solidnej podstawie źródłowej. W doborze materiału dążył do kompletności. Dużą wagę przywiązywał do odpowiedniego przygotowania bibliografii pod względem metodycznym. Stosował znormalizowany opis bibliograficzny. W miarę potrzeby wprowadzał opis skrócony i adnotowany. Do porządkowania materiału wykorzystywał układy rzeczowe i formalne. Większość bibliografii dopełnił stosownym aparatem informacyjno-pomocniczym. Troszczył się także o stronę edytorską spisów. Bibliografie lokalne opracowane przez Henryka Baranowskiego wzbudziły zainteresowanie świata naukowego i zostały pozytywnie ocenione.

SŁoWA KLUCzowe: Baranowski Henryk, bibliografia lokalna, historia, metodyka.

\section{Wprowadzenie}

enryk Baranowski, uznawany za jednego z najwybitniejszych pol-
skich bibliotekarzy i bibliografów, był autorem szeregu prac biblio- 
graficznych ${ }^{1}$. Wiele spośród nich jest dziełami pionierskimi o znaczeniu międzynarodowym. Wystarczy wymienić choćby trzytomową Bibliografię Wilna (Toruń 1996-2007), dwutomową Bibliografię miasta Torunia (Warszawa-Toruń 1972-1996) czy bieżącą Bibliografię historii Pomorza Wschodniego i Zachodniego, zapoczątkowaną zestawieniem za rok 1958, ogłaszaną w latach 1959-1998 w „Zapiskach Historycznych”, a od 1999 r. do chwili obecnej publikowaną jako suplement do tegoż periodyku². Każda z tych bibliografii należy do podstawowych źródeł informacji w warsztacie naukowym nie tylko badaczy polskich, ale też historyków obcych, zajmujących się dziejami miast oraz historią krajów regionu Bałtyku. Służą one pomocą także innym użytkownikom - regionalistom, bibliotekarzom, nauczycielom oraz studentom.

Mimo znaczącego wkładu H. Baranowskiego do rozwoju bibliografii polskiej, jego dorobek bibliograficzny nie był dotychczas przedmiotem szerzej zakrojonych badań. Jedynym wyjątkiem jest Bibliografia historii Pomorza Wschodniego i Zachodniego, która doczekała się szczegółowych analiz ${ }^{3}$. 0 innych bibliografiach wzmiankowano jedynie ogólnikowo w publikacji jubileuszowej, wydanej z okazji 70-lecia urodzin i 45-lecia pracy zawodowej bibliografa ${ }^{4}$ oraz $\mathrm{w}$ artykułach wspomnieniowych poświęconych jego osobie ${ }^{5}$.

1 Według Urszuli Zaborskiej, spośród 127 publikacji autorstwa H. Baranowskiego 77 stanowią bibliografie (U. Zaborska, Doktor Henryk Baranowski (1920-2011), „Zapiski Historyczne" 2011, T. 76, z. 2, s. 165).

2 Od zestawienia za rok 1968, ogłoszonego w 1970 r., spis wychodzi pt. Bibliografia historii Pomorza Wschodniego i Zachodniego oraz krajów regionu Bałtyku za rok... wraz z uzupełnieniami z lat poprzednich. Ostatnio ukazało się zestawienie za rok 2015, wydane w 2017 r., w opracowaniu są materiały z lat 2016-2018. Oprócz wersji drukowanej, od 1991 r. tworzona jest elektroniczna baza tejże bibliografii, gromadząca piśmiennictwo od 1989 r. Zob. Bibliografia historii Pomorza Wschodniego i Zachodniego oraz krajów regionu Bałtyku za rok 2015 wraz z uzupełnieniami z lat poprzednich, oprac. A. Biedrzycki, W. Szramowski, „Zapiski Historyczne” 2017, T. 82, suplement; Od Redakcji, „Zapiski Historyczne” 1999, T. 64, suplement, s. [4]; U. Zaborska, Bibliografia historii Pomorza Wschodniego i Zachodniego oraz krajów regionu Bałtyku, „Bibliotekarz” 2018, [nr] 4, s. 8, 12-13.

3 A. Matczuk, Rozwój metodyczny polskich bibliografii historycznych regionalnych, Lublin 1994, s. 169-177; B. Wachowiak, Henryka Baranowskiego Bibliografia historii Pomorza Wschodniego i Zachodniego oraz krajów regionu Bałtyku za lata 1959-1994 - jej charakter i znaczenie, „Zapiski Historyczne” 1994, T. 59, z. 2/3, s. 7-12.

${ }^{4}$ Homo bibliographicus. Henryka Baranowskiego zmagania z bibliografia, pod red. A. Domańskiego, M. A. Supruniuka, Toruń 2001.

${ }^{5}$ K. Przybyszewski, Henryk Baranowski (1920-2011), bibliotekarz i bibliograf, „, Rocz- 
W kręgu zainteresowań H. Baranowskiego były przede wszystkim bibliografie specjalne. Jego domenę stanowiły bibliografie osobowe, regionalne i lokalne. W ich obrębie tworzył spisy retrospektywne i bieżące, zestawiał bibliografie regionalne i lokalne ogólne, dziedzin i zagadnień oraz określonych form wydawniczych.

Celem artykułu jest prezentacja dorobku i osiągnięć H. Baranowskiego w zakresie bibliografii lokalnych. Starano się pokazać okoliczności powstania poszczególnych spisów oraz stosowane w nich rozwiązania metodyczne. W centrum uwagi znalazły się takie kwestie jak: dobór i selekcja materiału, opis bibliograficzny, sposób porządkowania zgromadzonego piśmiennictwa oraz aparat informacyjno-pomocniczy.

Badaniami objęto bibliografie lokalne o charakterze ogólnym. Pominięto natomiast bibliografie lokalne dziedzin i zagadnień oraz określonych form wydawniczych, bowiem zalicza się je do odrębnych rodzajów bibliografii specjalnych ${ }^{6}$. Posiadają one własną metodę opracowania, znacznie różniącą się od metodyki bibliografii lokalnych ogólnych, i dlatego wymagają oddzielnych analiz.

W rezultacie kwerendy przeprowadzonej w bibliografii osobowej H. Baranowskiego ${ }^{7}$ oraz w bieżącej „Bibliografii Bibliografii Polskich” ustalono, że przygotował on bibliografie lokalne pięciu miast, takich jak: Elbląg, Grudziądz, Słupsk, Toruń i Wilno.

Zanim jednak przejdziemy do zasadniczej problematyki, warto przypomnieć podstawowe fakty z biografii H. Baranowskiego. Pozwoli to lepiej scharakteryzować i zrozumieć jego działalność bibliograficzną.

nik Toruński” 2011, T. 38, s. 223-227; M. A. Supruniuk, Pan Henryk, „Głos Uczelni” 2011, nr 3, s. 22; (w), Odszedł wielki bibliograf, „Głos Uczelni” 2011, nr 3, s. 23; U. Zaborska, Doktor Henryk Baranowski..., s. 163-170; taż, Starszy kustosz dyplomowany dr Henryk Baranowski (1920-2011) „Folia Toruniensia” 2011, T. 11, s. 173-175.

${ }^{6}$ B. Eychler, Bibliografia regionalna i lokalna, [w:] Metodyka bibliograficzna. Poradnik dla autorów bibliografii specjalnych, pod red. H. Hleb-Koszańskiej, M. Dembowskiej, H. Sawoniaka, Wyd. 2 zm., Warszawa 1963, s. 299-301; taż, Z problemów teoretycznych bibliografii regionalnych, „Przegląd Biblioteczny” 1971, R. 39, z. 1-4, s. 141-149; J. Jaworska, Z problematyki łódzkiej bibliografii regionalnej, „Kronika Miasta Łodzi” 1976, s. $118-121$.

7 M. Nędzewicz, Bibliografia prac Henryka Baranowskiego za lata 1952-2000, [w:] Homo bibliographicus..., s. 47-57. 


\section{Sylwetka Henryka Baranowskiego}

Urodzony 7 października 1920 r. w Wilnie, H. Baranowski wychowywał się i kształcił w rodzinnym mieście. W 1930 r. rozpoczął naukę w prywatnym Gimnazjum oo. Jezuitów. Po jego ukończeniu w 1938 r., zwieńczonym świadectwem dojrzałości, podjął studia prawnicze na Uniwersytecie Stefana Batorego. Nie skończył ich jednak z powodu zamknięcia uczelni przez władze litewskie w grudniu 1939 r. Po zajęciu Wilna przez Niemców w czerwcu 1941 r., pracował jako pokojowy w hotelu „Georges”. W 1942 r., obawiając się wcielenia do armii niemieckiej, uciekł z Wilna do Niemenczyna, gdzie pod przybranym nazwiskiem pracował jako ogrodnik. Ujęty podczas „łapanki” w sierpniu 1943 r., został wysłany na roboty przymusowe do III Rzeszy. Pracował tam w wielu miejscach w organizacji Todta. Po powrocie do Polski, w sierpniu 1945 r. przybył do Torunia. Z miastem tym związał dalszą część swojego życia. W 1948 r. ukończył studia prawnicze na Uniwersytecie Mikołaja Kopernika [dalej UMK], a w 1952 r. sfinalizował na tej uczelni uzupełniające studia bibliotekarskie.

Studia łączył z pracą zawodową w Bibliotece Uniwersyteckiej. Rozpoczął ją w październiku 1945 r. jako wolontariusz. Rok później został pracownikiem kontraktowym. W latach następnych szybko awansował, zdobywając kolejne stopnie w profesji bibliotekarskiej: asystenta bibliotecznego (1951), starszego asystenta bibliotecznego (1954), kustosza (1960), kustosza dyplomowanego (1963), starszego kustosza dyplomowanego (1971).

W pierwszych latach swojej pracy zaangażował się czynnie w akcję zabezpieczania, zwożenia i opracowywania księgozbiorów przeznaczonych dla Biblioteki Uniwersyteckiej w Toruniu ${ }^{8}$.

W 1956 r. został kierownikiem Oddziału Gromadzenia i Uzupełniania Zbiorów. Sprawując tę funkcję, nieprzerwanie przez 29 lat, wydatnie przyczynił się do powiększenia księgozbioru Biblioteki, nierzadko o dzieła unikatowe i poszukiwane. Znając potrzeby środowiska naukowego, troszczył się o to, aby wśród nabytków bibliotecznych były zarówno dzieła o charakterze uniwersalnym, jak też specjalistycznym, w głównej mierze

${ }^{8}$ M. Puciatowa, Biblioteka Główna, [w:] Uniwersytet Mikołaja Kopernika 1945-1955, Warszawa 1957, s. 313. 
dotyczące zagadnień pomorzoznawczych i bałtoznawczych. Dzięki swoim wysiłkom i zabiegom nie tylko zgromadził cenny księgozbiór, pozwalający uczonym na prowadzenie wielopłaszczyznowych badań naukowych, ale też przyczynił się do powstania w 1975 r. Czytelni Pomorzoznawczej, która stała się miejscem pracy wielu uczonych europejskich, reprezentujących rozmaite dziedziny wiedzy.

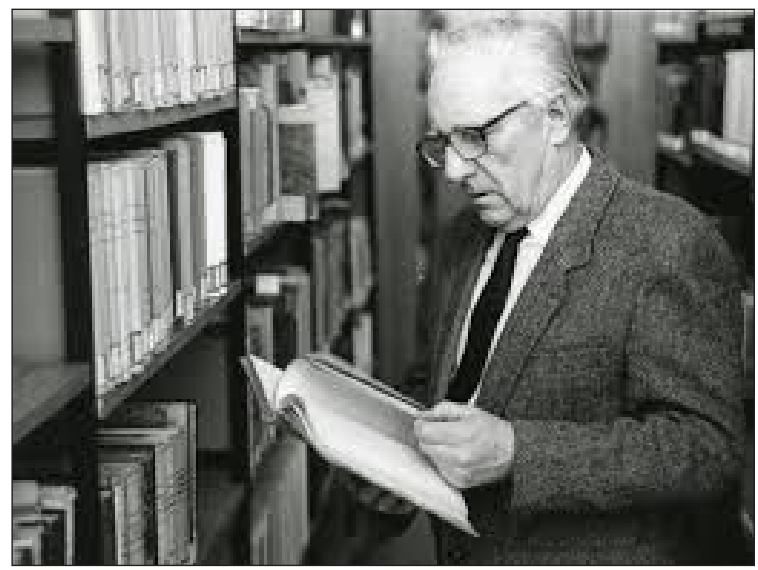

Ilustracja 1. Henryk

Baranowski

Źródło: https://

pomorska.pl/torun-

zmarl-wybitny-

bibliograf-henryk-

baranowski/ar/7210918

Rozwojowi kariery zawodowej towarzyszyły awanse naukowe. W 1975 r. H. Baranowski otrzymał stopień doktora nauk humanistycznych na podstawie rozprawy zatytułowanej Bibliografia miasta Torunia na tle bibliografii historycznych Pomorza Wschodniego i bibliografii miast Pomorza i pozostałych regionów Polski, przygotowanej pod kierunkiem wybitnego historyka dziejów zakonu krzyżackiego, badacza dziejów Pomorza i krajów regionu Bałtyku, specjalizującego się w okresie XIII-XVI w., prof. dr. hab. Mariana Biskupa.

W 1984 r. H. Baranowski objął stanowisko zastępcy dyrektora Biblioteki Uniwersyteckiej w Toruniu, a w roku następnym został zatrudniony jako docent kontraktowy w Zakładzie Bibliotekoznawstwa i Informacji Naukowej UMK. W 1986 r. przeszedł na emeryturę z powodu pogarszającego się stanu zdrowia. Nie rozstał się jednak zupełnie z Biblioteką. Pracował w niej na pół etatu do 1993 r., a potem jeszcze przez wiele lat prowadził badania naukowe w Czytelni Pomorzoznawczej. 
Oprócz pracy zawodowej aktywnie działał w Towarzystwie Naukowym w Toruniu, gdzie pełnił m.in. funkcję przewodniczącego Komisji Bibliografii i Bibliotekoznawstwa i wydawał część swoich publikacji. Wiele energii wkładał także w działalność w Towarzystwie Bibliofilów im. Joachima Lelewela w Toruniu, będąc najpierw sekretarzem, potem wiceprezesem i w końcu prezesem tegoż stowarzyszenia.

Za swoją pracę i zasługi $\mathrm{H}$. Baranowski był wielokrotnie odznaczany. Otrzymał m.in. Krzyż Kawalerski Orderu Odrodzenia Polski w 1987 r. i Medal Komisji Edukacji Narodowej w 1992 r. Został także uhonorowany Złotą Odznaką UMK, Medalem za Zasługi dla Rozwoju Uczelni, Złotym Krzyżem Zasługi i Medalem 40-lecia UMK. Zmarł w Toruniu 3 marca 2011 r.

Podejmując pracę w Bibliotece Uniwersyteckiej, H. Baranowski realizował swoje zamiłowania do książki i czytelnictwa, zrodzone jeszcze w okresie wczesnej młodości. Jak sam przyznał:

Już od V klasy (starego typu) pracowałem w szkolnej bibliotece, nigdy jednak nie miałem chęci kolekcjonowania, po prostu lubiłem czytać i mieć kontakt z książką9

W Bibliotece Uniwersyteckiej zetknął się z szeregiem wybitnych polskich bibliotekarzy, często wywodzących się, podobnie jak on, z ziemi wileńskiej, niejednokrotnie o zainteresowaniach bibliograficznych, którzy z pewnością mieli znaczący wpływ na kształtowanie i rozwijanie zainteresowań nie tylko bibliotecznych, ale też bibliograficznych młodego pracownika.

Dużą wiedzę i doświadczenie bibliograficzne, nabyte jeszcze w okresie międzywojennym, posiadał pierwszy dyrektor Biblioteki Uniwersyteckiej w Toruniu Stefan Burhardt. O wartości jego dokonań świadczy fakt, że za swoją pracę na polu bibliotekarstwa i bibliografii został odznaczony Złotym Krzyżem Zasługi ${ }^{10}$. Bibliografią interesował się także kustosz Biblioteki Stanisław Lisowski ${ }^{11}$. To właśnie z jego inicjatywy H. Baranowski

${ }^{9}$ Homo bibliographicus..., s. 33-34.

10 H. Baranowski, Doktor Stefan Burhardt, „Głos Uczelni” 1980, nr 3-4, s. 47.

11 L. Jarzębowski, Lisowski Stanisław (1880-1964), [w:] Polski słownik biograficzny, t. 17, Wrocław 1972, s. 475-476; tenże, Lisowski Stanisław, [w:] Słownik pracowników książki polskiej, Warszawa 1972, s. 521. 
przystąpił pod koniec lat 40. XX w. do gromadzenia materiałów do bibliografii osobowej Mikołaja Kopernika ${ }^{12}$. W ten oto sposób rozpoczął swoją twórczość bibliograficzną, intensywnie rozwijaną w latach następnych. Z upływem czasu oprócz bibliografii osobowej zaczął zajmować się także innymi rodzajami bibliografii, w tym bibliografią lokalną.

\section{Geneza bibliografii lokalnych}

Przedstawiając okoliczności powstania bibliografii lokalnych, warto na wstępie przytoczyć słowa H. Baranowskiego, który stwierdził, że

[...] to, co robiłem - robiłem nie dla pochwał, ale z wewnętrznej potrzeby, a później nawet i z obowiązku, wiedziałem bowiem, że te bibliografie są po prostu przydatne, że są wykorzystywane, są oczekiwane ${ }^{13}$.

Wewnętrzna potrzeba i poczucie obowiązku były zatem zasadniczymi przyczynami tworzenia przez $\mathrm{H}$. Baranowskiego bibliografii lokalnych. Ponadto dochodziła jeszcze jego świadomość braków i zaniedbań na tym polu w Polsce. Dlatego, starając się nadrobić istniejące zaległości, podejmował kolejne inicjatywy bibliograficzne o charakterze lokalnym.

Pierwszą bibliografią lokalną przygotowaną przez $\mathrm{H}$. Baranowskiego była niewielka, bo licząca zaledwie 40 pozycji, bieżąca bibliografia Grudziądza, zatytułowana Publikacje dotyczqce Grudziq̨dza i jego regionu w latach 1954-1959, ogłoszona w 1960 r. na łamach pierwszego tomu „Rocznika Grudziądzkiego”"14. Jej geneza wiąże się ściśle z rozwojem polskiej historiografii regionalnej i lokalnej, który nastąpił w Polsce po 1956 r. i był szczególnie widoczny na obszarze Ziem Zachodnich i Północnych. U podłoża zainteresowań badaczy wymienionym terenem leżało zapotrzebowanie społeczne oraz względy polityczne. Podjęcie badań przez historyków zmierzało do przybliżenia tradycji polskich na tych ziemiach, co miało

${ }^{12}$ Homo bibliographicus..., s. 34; A. Supruniuk, M. A. Supruniuk, Bibliotekarz i bibliograf. Pół wieku pracy dra Henryka Branowskiego na UMK, „Głos Uczelni” 1994, nr 1, s. 6.

13 Tamże, s. 33.

14 H. Baranowski, Publikacje dotyczące Grudziądza i jego regionu w latach 1954-1959, „Rocznik Grudziądzki” 1960, T. [1], s. 313-315. 
doprowadzić do pełnej integracji kulturowej społeczeństwa mieszkającego na tym obszarze. W tym celu w 1957 r. założono Towarzystwo Rozwoju Ziem Zachodnich. Z inicjatywy tegoż stowarzyszenia zorganizowano wiele placówek, zajmujących się upowszechnianiem wiedzy historycznej.

Rozwojowi badań naukowych towarzyszył rozwój bibliografii regionalnych i lokalnych dla Ziem Zachodnich. Ich zadaniem było z jednej strony wspieranie i upowszechnianie wyników prac badawczych, z drugiej zaś miały być przeciwwagą dla niekompletnych i tendencyjnych bibliografii wydawanych $w$ tym czasie na terenie Niemiec Zachodnich ${ }^{15}$.

W okresie intensywnych prac na polu organizacji nauki historycznej na Pomorzu, powstał w Grudziądzu Oddział Polskiego Towarzystwa Historycznego. Został on powołany do życia 11 listopada 1956 r. $^{16}$ Jego podstawowym zadaniem, oprócz prowadzenia badań naukowych, było szerzenie wiedzy historycznej wśród szerokich rzesz społecznych. Pomocą w realizacji tego zamierzenia miał służyć periodyk „Rocznik Grudziądzki”, redagowany przez M. Biskupa i Stanisława Myśliborskiego-Wołowskiego, oraz publikowana na jego łamach bibliografia. Głównym inicjatorem stworzenia bibliografii Grudziądza był zapewne M. Biskup. Jako historyk i zarazem inspirator wcześniejszych prac bibliograficznych, doskonale zdawał sobie sprawę $\mathrm{z}$ wagi i znaczenia bibliografii $\mathrm{w}$ badaniach naukowych i szerzeniu wiedzy historycznej ${ }^{17}$. Stąd wyposażył nowopowstałe czasopismo, poczynając od pierwszego numeru, w stały dział bibliograficzny.

Bieżąca bibliografia Grudziądza zapoczątkowana przez H. Baranowskiego w 1960 r. jest kontynuowana po dzień dzisiejszy. Sukcesywnie na łamach „Rocznika Grudziądzkiego” ogłaszane są kolejne zestawienia publikacji o tym mieście ${ }^{18}$. Świadczy to najlepiej o roli i znaczeniu przedsięwzięcia zainicjowanego przez toruńskiego bibliografa.

Początek lat 60. XX w. przyniósł dwie kolejne bibliografie lokalne autorstwa H. Baranowskiego, obydwie poświęcone Elblągowi. W $1961 \mathrm{r}$.

15 A. Matczuk, dz. cyt., s. 30.

${ }^{16}$ S. Myśliborski-Wołowski, Polskie Towarzystwo Historyczne Oddział w Grudziądzu, „Rocznik Grudziądzki” 1960, T. [1], s. 295.

17 Z inicjatywy M. Biskupa powstała bibliografia historii Pomorza Wschodniego i Zachodniego. Zob. A. Matczuk, dz. cyt., s. 170; U. Zaborska, Bibliografia historii Pomorza..., s. 8.

18 Ostatni spis rejestruje piśmiennictwo z 2016 r. Zob. K. Furmańska, Bibliografia grudziądzka za rok 2016, „Rocznik Grudziądzki” 2017, T. 25, s. 406-426. 
wydał retrospektywną Bibliografię historii Elblaga i regionu za lata 1945-1960, zamieszczoną w pierwszym tomie „Rocznika Elbląskiego” ${ }^{19}$. Dwa lata później ogłosił Bibliografię historii Elblagga i regionu za rok 1961 wraz $z$ uzupełnieniami od roku $1945^{20}$. Tym ostatnim spisem rozpoczął edycję bieżącej bibliografii Elbląga, która jest tworzona przez jego następców do chwili obecnej ${ }^{21}$.

Bibliografia Elbląga zrodziła się w podobnych okolicznościach, jak bibliografia Grudziądza. Zasadniczy wpływ na jej powstanie miała organizacja w Elblągu ośrodka badań historycznych. Dnia 17 stycznia 1957 r. powołano w tym mieście Oddział Polskiego Towarzystwa Historycznego ${ }^{22}$. Ambicją tej placówki było prowadzenie badań naukowych nad dziejami miasta oraz krzewienie ich wyników na łamach własnego periodyku. Dzięki zabiegom miejscowych miłośników historii i nawiązaniu kontaktu z toruńskim środowiskiem historycznym w 1961 r. zaczęto ogłaszać „Rocznik Elbląski”, powierzając stanowisko redaktora naczelnego M. Biskupowi. W kierowanym przez siebie czasopiśmie, wzorem „Rocznika Grudziądzkiego”, przeznaczył on stałe miejsce dla bibliografii Elbląga, która, jak sam stwierdził

[...] stanowiła dodatkowe ułatwienie dla przyszłych badaczy przeszłości miasta i jego zaplecza ${ }^{23}$.

Z pewnością miała ona służyć także pomocą w przygotowaniu planowanej syntezy dziejów Elbląga i jego regionu ${ }^{24}$.

19 H. Baranowski, Bibliografia historii Elblaga i regionu za lata 1945-1960, „Rocznik Elbląski" 1961, T. 1, s. 245-250.

20 Tenże, Bibliografia historii Elblaga i regionu za rok 1961 wraz z uzupełnieniami od roku 1945, „Rocznik Elbląski” 1963, T. 2, s. 329-332.

${ }^{21}$ Ostatnie zestawienie obejmuje piśmiennictwo za lata 2010-2015. Zob. K. Greczycho, Bibliografia Elblagga za lata 2010-2015 wraz z uzupełnieniami z lat poprzednich, „Rocznik Elbląski” 2015, T. 26, s. 191-214.

22 W. Sierzputowski, Powstanie i działalność Oddziału Polskiego Towarzystwa Historycznego w Elblagu w latach 1957-1960, „Rocznik Elbląski” 1961, T. 1, s. 227.

${ }_{23}$ M. Biskup, Ze wspomnień o powstaniu i początkach Rocznika Elbląskiego, „Rocznik Elbląski" 2006, T. 20, s. 18.

${ }_{24}$ Tenże, Potrzeby historiograficzne Elblaga i jego regionu, „Rocznik Elbląski” 1961, T. 1, s. 29. 


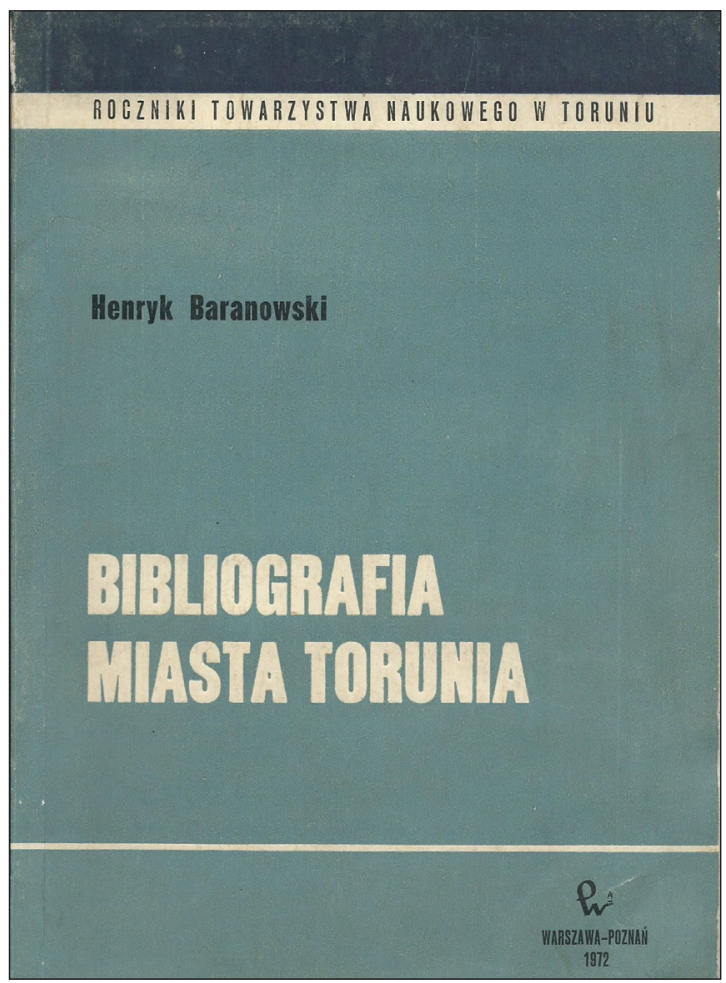

Ilustracja 2. Okładka

Bibliografii Miasta Torunia

[T. 1]. Warszawa-Poznań 1972.

Źródło: Biblioteka Główna UMCS.

Zapotrzebowanie naukowe i społeczne przyczyniło się także do powstania bibliografii Torunia. H. Baranowski pracował nad nią od połowy lat 50. XX wieku, kiedy to wspólnie z kustosz Książnicy Miejskiej w Toruniu Emmą Skobejko zaczął gromadzić pierwsze materiały ${ }^{25}$. W efekcie podjętych działań w 1972 r. samodzielnie wydał retrospektywną Bibliografię miasta Torunia (Warszawa), rejestrującą piśmiennictwo za lata 1531-1971. Bibliografia wzbudziła duże zainteresowanie wśród odbiorców, zyskała pochlebne opinie recenzentów ${ }^{26}$ oraz stała się podstawą rozprawy doktorskiej autora spisu. Odniesiony sukces skłonił bibliografa

${ }^{25}$ Homo bibliographicus..., s. 35.

${ }^{26}$ H. Baranowski, Bibliografia miasta Torunia, Warszawa 1972, zob. rec. A. Heise, „Ostdeutscher Literatur-Anzeiger” 1973, Jg. 19, H. 3, s. 104-105; J. Kasprzyk, „Rocznik Kulturalny Kujaw i Pomorza” 1973/1974, T. 8, s. 230-231; G. L. [G. Labuda], „Studia Źródłoznawcze” 1976, [T.] 20, s. 265-266; W. Maisel, „Zapiski Historyczne” 1974, T. 39, z. 1, s. $123-125$. 
do przygotowania następnych wykazów publikacji o Toruniu, obejmujących lata 1972-1989. Zostały one ogłoszone w czterech częściach na łamach „Rocznika Toruńskiego" ${ }^{27}$. Autor zdawał sobie sprawę z tego, że korzystanie z tej bibliografii było niewygodne z powodu rozproszenia materiałów, dlatego powziął decyzję skomasowania poszczególnych spisów, dopełnienia ich materiałami sprzed 1972 r. oraz z lat 1990-1993. W ten sposób doszło do wydania drugiego tomu Bibliografii miasta Torunia (Toruń 1996), gromadzącego piśmiennictwo za lata 1972-1993 oraz uzupełnienia z lat wcześniejszych. Opublikowana bibliografia, podobnie jak jej pierwszy tom, nie uszła uwadze krytyków. Recenzenci dostrzegli ją i bardzo pozytywnie ocenili, uznali wręcz za modelowo przygotowaną bibliografię lokalną ${ }^{28}$. W związku z tym, że nakład pierwszego tomu bibliografii Torunia uległ wyczerpaniu, a cieszyła się ona nadal dużym zainteresowaniem czytelników, w 1999 r. doszło do jej wznowienia.

Opublikowana w 1972 r. Bibliografia i kolejne jej części niemal od razu zostały wykorzystane przez toruńskich historyków, którzy na początku lat 70. XX w. podjęli inicjatywę opracowania syntezy dziejów Torunia. Przyczyniła się ona do przyspieszenia badań nad historią miasta oraz ułatwiła opracowanie jednotomowej monografii, zatytułowanej Toruń dawny i dzisiejszy. Zarys dziejów, wydanej pod redakcją M. Biskupa (Warszawa 1983) ${ }^{29}$.

W trakcie pracy nad zestawieniami publikacji o Toruniu H. Baranowski przygotował retrospektywną bibliografię Słupska. Została ona opublikowana jako dopełnienie monografii poświęconej dziejom mia-

27 H. Baranowski, Bibliografia miasta Torunia. Materiały z lat 1972-1974 oraz uzupetnienia z lat poprzednich, „Rocznik Toruński” 1975, R. 10, s. 333-361; tenże, Bibliografia miasta Torunia. Materiały z lat 1975-1978 wraz z uzupełnieniami z okresu wcześniejszego, „Rocznik Toruński” 1979, R. 14, s. 43-86; tenże, Bibliografia miasta Torunia. Materiały z lat 1979-1983 wraz z uzupełnieniami z okresu wcześniejszego „,Rocznik Toruński” 1986, R. 17, s. 281-357; Bibliografia miasta Torunia. Materiały z lat 1984-1989 wraz z uzupełnieniami z okresu wcześniejszego, „Rocznik Toruński” 1991, R. 20, s. 295-390. Podobnie, jak w przypadku bibliografii Grudziądza i Elbląga, bieżąca bibliografia Torunia jest nadal tworzona. Ostatnie zastawienie zob. A. Biedrzycki, Bibliografia miasta Torunia za rok 2018 wraz z uzupełnieniami, „Rocznik Toruński” 2019, T. 46, s. 411-500.

${ }^{28}$ H. Baranowski, Bibliografia miasta Torunia, t. 2, 1972-1993 wraz z uzupełnieniami, Toruń 1996, zob. rec. A. Matczuk, „Folia Bibliologica” 1996/1997, R. 44/45, s. 120 ; J. Borzyszkowski, „Pomerania” 1997, nr 6, s. 72.

${ }_{29}$ Homo bibliographicus..., s. 16; M. Biskup, Koncepcje i realizacja syntezy historii Torunia, „Rocznik Toruński” 1996, T. 23, s. 23. 
sta nad Słupią ${ }^{30}$. Bibliografia nie tylko dokumentowała piśmiennictwo dotyczące Słupska, ale też stanowiła zachętę do prowadzenia dalszych wieloaspektowych badań miasta.

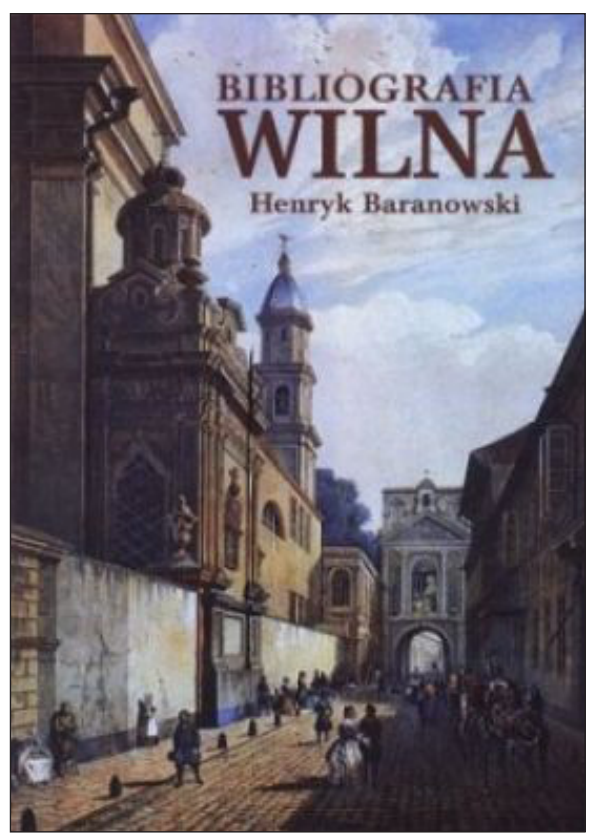

Ilustracja 3. Okładka Bibliografii

Wilna. T. 2: Miasto. Toruń 2000.

Źródło: Biblioteka Główna UMCS.

Przypadający w 1979 r. jubileusz 400-lecia powstania Uniwersytetu Wileńskiego stał się bezpośrednią przyczyną przygotowania przez H. Baranowskiego spisu zatytułowanego Uniwersytet Wileński 1579-1939. Bibliografia za okres 1945-1982 (Wrocław 1983). Tym zestawieniem zagadnieniowym zapoczątkował publikowanie bibliografii wileńskich. Jako następną wydał bibliografię poświęconą Matce Boskiej Ostrobramskiej i jej Sanktuarium pt. Ostra Brama. Bibliografia (Toruń 1991). Ukoronowaniem całego przedsięwzięcia była trzytomowa Bibliografia Wilna (Toruń 1996, 2000, 2007). Jej pierwszy tom odnosi się do dziejów Uniwersytetu Wileńskiego, a dwa pozostałe dotyczą całokształtu życia miasta od jego

${ }^{30}$ H. Baranowski, Bibliografia [Słupska], [w:] Historia Słupska, pod red. S. Gierszewskiego, Poznań 1981, s. 577-602. 
początków do maja 1945 r. Wydane bibliografie zostały dostrzeżone i życzliwie przyjęte przez krytyków ${ }^{31}$.

H. Baranowski uważał tworzenie i wydawanie bibliografii Wilna za swoją powinność i wewnętrzny obowiązek. Przez stworzenie dokumentacji piśmiennictwa pragnął uchronić je od zapomnienia oraz wyrazić wdzięczność miastu, w którym się urodził, spędził dzieciństwo i młodośćc ${ }^{32}$. Trzeba przyznać, że bibliograf w pełni zrealizował swoje zamierzenie. Dzięki jego pracy Wilno, podobnie jak Toruń, należy do nielicznych miast polskich, mogących poszczycić się monumentalną retrospektywną bibliografią przedmiotową.

\section{Metoda opracowania bibliografii lokalnych. Dobór i selekcja materiału}

Lektura przedmów i wstępów do bibliografii Torunia i Wilna pozwala stwierdzić, że H. Baranowski oparł obydwa zestawienia na bardzo szerokiej podstawie źródłowej. Gromadząc materiał do Bibliografii miasta Torunia, wykorzystał polską retrospektywną i bieżącą bibliografię narodową (Bibliografię polskq Karola Estreichera, „Przewodnik Bibliograficzny”, „Bibliografię Zawartości Czasopism”), bibliografie dziedzinowe z zakresu historii (m.in. retrospektywną Bibliografię historii polskiej Ludwika Finkla, bieżącą „Bibliografię Historii Polskiej”, Bibliografię historii Pomorza Wschodniego i Zachodniego, Bibliographie der Geschichte von Ost- Und Westpreussen Ernsta Wermkego) oraz inne bibliografie specjalne. Kwerendę przeprowadził w katalogach toruńskich bibliotek,

${ }^{31}$ H. Baranowski, Bibliografia Wilna, t. 2, Miasto, przy współpr. z Z. Baranowską, J. Goławską, Toruń 2000, zob. rec. H. Dubowik, Bibliografia Wilna - opus magnum Henryka Baranowskiego, „Wileńskie Rozmaitości” 2001, nr 2, s. 17; D. Kazlauskienė, Ž. Petrauskienè, Lenkijos mokslininko Vilniaus bibliografija, „Tarp Knygy” 2001, nr 6, s. 34-35; S. Łowkis, Uzupełnienia do Bibliografii Wilna, „Wileńskie Rozmaitości” 2002, nr 2, s. 11-12; H. Baranowski, Bibliografia Wilna, t. 3, Za lata 1999-2005 oraz uzupełnienia, przy współpr. J. Goławskiej, Toruń 2007, zob. rec. M. Kosman, „Zapiski Historyczne” 2009, T. 74, z. 3, s. $141-143$.

32 Homo bibliographicus..., s. 36; A. Supruniuk, M. A. Supruniuk, O czym myśli bibliograf? Jubileusz dr. Henryka Baranowskiego, „Głos Uczelni” 2001, nr 3, s. 10; A. Jamiołkowski, Henryk Baranowski - obywatel Wilna i Torunia, [w:] H. Baranowski, Bibliografia Wilna, t. 3..., s. XII. 
w Archiwum Państwowym w Toruniu oraz w katalogu Herzog August Bibliothek w Wolffenbüttel. Skorzystał z Polskiego słownika biograficznego oraz Altpreussische Biographie. Przejrzał również komplet polskich i niemieckich czasopism historycznych poświęconych dziejom Torunia, Prus i Pomorza oraz zapoznał się z zawartością całej polsko- i niemieckojęzycznej toruńskiej prasy codziennej ${ }^{33}$.

Materiał do Bibliografii Wilna autor czerpał z równie rozległych i zróżnicowanych wydawnictw informacyjnych. Wśród nich znalazły się, podobnie jak w przypadku Torunia, polskie bibliografie narodowe, wzbogacone dodatkowo o Bibliografię polskq 1901-1939 i „Polonika Zagraniczne", bibliografie dziedzinowe, nie tylko historyczne, ale też z zakresu sztuki (Polska bibliografia sztuki), literatury (Bibliografia literatury polskiej „Nowy Korbut”, „Polska Bibliografia Literacka”) oraz dotyczące dziejów Kościoła („Bibliografia Historii Kościoła w Polsce”). Wykorzystał również retrospektywne Bibliografie bibliografii polskich Wiktora Hahna i Henryka Sawoniaka oraz istniejące bibliografie Wilna. Oprócz polskich źródeł bibliograficznych, poszukiwał piśmiennictwa w narodowych i dziedzinowych bibliografiach litewskich oraz w zestawieniach niemieckich dotyczących Litwy. Materiał pozyskiwał także z katalogów wielu polskich i wileńskich bibliotek, z licznych czasopism i słowników biograficznych oraz z elektronicznych baz danych ${ }^{34}$.

W bibliografiach Grudziądza, Elbląga i Słupska H. Baranowski nie określił podstawy źródłowej. Biorąc jednak pod uwagę różnorodność zarejestrowanego piśmiennictwa, można sądzić, że podczas gromadzenia materiału posiłkował się rozmaitymi źródłami informacji.

Zasadniczym celem tak wnikliwej kwerendy było nadanie poszczególnym bibliografiom najwyższego stopnia kompletności w ramach przyjętych założeń doboru i selekcji materiału. Realizacji tego zamierzenia służyły też uzupełnienia zamieszczone w większości bibliografii.

Wszystkie analizowane zestawienia należą do grupy bibliografii lokalnych przedmiotowych. Mają one charakter ogólny, aczkolwiek zakres

${ }^{33}$ Więcej szczegółów na temat materiałów źródłowych zob. H. Baranowski, Przedmowa, [w:] tenże, Bibliografia miasta Torunia..., s. XII-XIII oraz tenże, Wstęp, [w:] tenże, Bibliografia miasta Torunia, t. 2..., s. XI.

${ }_{34}$ Listę wydawnictw źródłowych zob. H. Baranowski, Wstęp, [w:] tenże, Bibliografia Wilna, t. 2 ..., s. XI, XIV-XV oraz tenże, Wstęp, [w:] tenże, Bibliografia Wilna, t. 3..., s. XV, XIX. 
poszczególnych spisów cechuje się pewnym zróżnicowaniem. Najpełniejszym zakresem legitymują się bibliografie Torunia i Wilna. Ukazują one obydwa miasta we wszystkich aspektach życia. Prezentują ich historię, środowisko przyrodnicze, zagadnienia prawno-administracyjne, społeczne, narodowościowe, wyznaniowe, gospodarcze i komunalne. Ujmują wojskowość, architekturę i budownictwo, kulturę, oświatę, naukę, sztukę, sport, literaturę piękną, przedstawiają życie codzienne oraz sylwetki osób zasłużonych i w różny sposób związanych z każdym z miast.

Nieco inaczej sprawa zakresu wygląda w bibliografiach Elbląga, Grudziądza i Słupska. Autor wyeksponował w nich ujęcie historyczne. Nie znaczy to jednak, że mają one zakres ograniczony wyłącznie do prac z tej dziedziny. Zestawiają również publikacje odnoszące się do zagadnień współczesnych, m.in. spraw społeczno-politycznych, administracji, gospodarki, turystyki, kultury i szkolnictwa.

Wśród badanych bibliografii występują spisy retrospektywne i bieżące. Chronologię wydawniczą bibliografii retrospektywnych wyznaczają daty graniczne ogłoszenia pierwszej i ostatniej zarejestrowanej publikacji. Niekiedy widnieją one w tytule bibliografii, ale nie jest to regułą. Dotyczy to bibliografii Torunia, Wilna i Słupska. Z przeprowadzonej analizy wynika, że pierwsza z nich uwzględnia publikacje wydane w latach 1531-1993, przy czym najstarszą zarejestrowaną pozycję stanowi druk pt. Edictum ut moneta nova Cracouiae, Thoruni et ducis Prussiae excusa sit in usu datum Cracouiae 19 Apr. a. 1531. Natomiast Bibliografia Wilna dokumentuje prace dotyczące dziejów miasta od jego początku do maja 1945 r. Dolną granicę chronologii wydawniczej w tym zestawieniu wyznacza rok 1532, kiedy to ukazała się publikacja Grzegorza z Szamotuł pt. Sermo de indulgentiis bullaque iubilei pro fabrica ecclesie Cathedralis Vilnensis, a sede apost. Concessae. Resolutio 1532 (Cracoviae 1532), górna zaś granica zamyka się na roku 2005. Z kolei bibliografia Słupska odnotowuje piśmiennictwo ogłoszone w latach 1625-1979.

Zasięg chronologiczny bieżącej bibliografii Elbląga określa rok wydania zarejestrowanych dokumentów (1961). Dążąc do kompletności w doborze materiału, autor zawarł w tym spisie także uzupełnienia od 1945 r. Bibliografie bieżące Grudziądza i Torunia, ogłoszone w „Roczniku Toruńskim”, obejmują nieco dłuższe przedziały czasu. Zestawienie odnoszące się do Grudziądza rejestruje materiał za sześciolecie (1954-1959), a poszczególne części bibliografii Torunia gromadzą piśmiennictwo za 
okresy kilkuletnie wraz z uzupełnieniami z lat wcześniejszych. W obu przypadkach o zakwalifikowaniu publikacji do bibliografii decydowała data jej wydania.

Analizowane bibliografie rejestrują piśmiennictwo dotyczące poszczególnych miast, niezależnie od miejsca wydania. Zestawiają prace ogłoszone w Polsce i za granicą. Odnotowują dzieła Polaków oraz autorów obcych opublikowane w różnych językach. Warto zauważyć, że największym zróżnicowaniem pod względem zasięgu językowego cechuje się bibliografia Wilna - miasta, którego skarbem była wielokulturowość i wielojęzyczność. Oprócz publikacji w języku polskim, uwzględnia ona prace aż w 19 językach obcych, takich jak: litewski, rosyjski, angielski, niemiecki, francuski, jidysz, łaciński, białoruski, hebrajski, włoski, holenderski, szwedzki, hiszpański, węgierski, czeski, łotewski, duński, norweski, a nawet esperanto ${ }^{35}$. Z kolei bibliografie Elbląga i Grudziądza wykazują publikacje tylko w języku polskim i niemieckim, co wynika ze specyfiki dziejowej tych miast. Na przestrzeni wieków przeplatały się w nich wpływy polskie i niemieckie.

Zasięg wydawniczo-formalny analizowanych bibliografii jest nieograniczony. Zestawiają one druki samoistne pod względem wydawniczym (książki, broszury, odbitki, czasopisma), utwory i fragmenty bibliograficzne. Wśród utworów bibliograficznych widnieją artykuły z czasopism, rozprawy z dzieł zbiorowych oraz, co jest godne podkreślenia, artykuły z ogólnopolskiej i lokalnej prasy codziennej, które najczęściej pomijają inne bibliografie, w tym narodowa i dziedzinowe. Rejestrację artykułów prasowych docenili recenzenci, stwierdzając, że

Bez Bibliografii pamięć o nich zanikłaby bardzo szybko - dzięki niej mają szansę pozostania w obiegu informacyjnym ${ }^{36}$.

Tego typu publikacje są niewątpliwie ważne z punktu widzenia odbiorcy choćby z tego powodu, że zawierają szereg cennych informacji przydatnych np. w poznawaniu życia codziennego ośrodków miejskich. Krytycy

${ }^{35}$ H. Baranowski, Wstęp, [w:] tenże, Bibliografia Wilna, t. 2..., s. XIII; tenże, Wstęp, [w:] tenże, Bibliografia Wilna, t. 3..., s. XVI.

${ }^{36}$ H. Baranowski, Bibliografia miasta Torunia, t. 2..., rec. J. Serczyk, „Rocznik Toruński" 1997, T. 24, s. 269. 
chwalili H. Baranowskiego także za uwzględnienie fragmentów bibliograficznych, nie tylko z tego powodu, że ich poszukiwanie wymagało wiele czasu i wysiłku, ale też dlatego, że są wartościowe i przydatne dla szerokiego gremium czytelników ${ }^{37}$.

Pod względem piśmienniczym uwzględniają publikacje naukowe, popularnonaukowe i popularne. Wykazują prace indywidualne, współautorskie, redakcyjne, edytorskie i tłumaczenia. Opisują źródła i opracowania. Rejestrują bibliografie, encyklopedie, informatory, przewodniki, rozporządzenia, sprawozdania, wspomnienia, pamiętniki, dzienniki, teksty literackie, biografie, hasła słownikowe i encyklopedyczne, recenzje, polemiki oraz wywiady. Zestawiają stare druki, dokumenty życia społecznego, kartograficzne, ikonograficzne oraz druki muzyczne.

Jeszcze szerszy wachlarz zarejestrowanych materiałów zawiera retrospektywna Bibliografia miasta Torunia. Oprócz prac drukowanych, autor włączył do niej także dokumenty niepublikowane, tj. prace doktorskie i magisterskie oraz maszynopisy prac dokumentacyjno-historycznych wykonanych przez Pracownię Konserwacji Zabytków w Toruniu, a w jej pierwszym tomie odnotował również materiały rękopiśmienne. Decyzja o rejestracji maszynopisów prac doktorskich i magisterskich spotkała się z pozytywnym przyjęciem przez recenzentów ${ }^{38}$. Natomiast zestawienie rękopisów nie zyskało ich aprobaty ${ }^{39}$. H. Baranowski zgodził się ze stanowiskiem recenzentów i w drugim tomie Bibliografii miasta Torunia zrezygnował z wykazywania prac rękopiśmiennych.

Biorąc pod uwagę sprawę selekcji trzeba powiedzieć, że żadna $\mathrm{z}$ analizowanych bibliografii nie jest spisem kompletnym. Autor świadomie przeprowadzał w nich selekcję merytoryczną, pomijając z reguły wiadomości kronikarskie oraz publikacje o znikomej bądź żadnej wartości, pochodzące najczęściej z czasopism popularnych i prasy codziennej. W niektórych zestawieniach wprowadził jeszcze ostrzejsze kryteria selekcji. W retrospektywnej bibliografii Elbląga wykazał tylko ważniejsze pozycje, ograniczając jednocześnie rejestrację publikacji niemieckich. Można sądzić, że chodziło o wyeliminowanie prac tendencyjnych i re-

37 Por. W. Maisel, dz. cyt., s. 124; A. Matczuk, „Folia Bibliologica”..., s. 119.

38 Tamże; J. Serczyk, dz. cyt., s. 268; zob. też A. Znajomski, Bibliografie lokalne w opinii krytyków, „Przegląd Biblioteczny” 2018, R. 86, z. 3, s. 379.

39 W. Maisel, dz. cyt., s. 124. 
wizjonistycznych wydawanych po II wojnie światowej na terenie Niemiec Zachodnich. Z kolei w retrospektywnej Bibliografii miasta Torunia, spośród planów i widoków miasta, autor uwzględnił jedynie materiały o charakterze ogólnym, pominął zaś plany i widoki poszczególnych ulic i obiektów. Ze względu na problematyczną wartość nie zarejestrował również większości toruńskich XVII- i XVIII-wiecznych panegiryków.

Selekcję piśmiennictwa przeprowadził także w stosunku do osób i instytucji, które już dysponowały własnymi bibliografiami, bądź takie spisy były w trakcie przygotowania. Dotyczyło to M. Kopernika i Samuela Bogumiła Lindego. W przypadku obu uczonych bibliograf zamieścił tylko wybrane pozycje traktujące o ich związkach z Toruniem. Podobnie postąpił z publikacjami na temat UMK. Ograniczył ich dobór jedynie do dzieł bardziej istotnych. Selektywnie potraktował także materiały biograficzne uczonych związanych z uniwersytetem toruńskim. Spośród nich uwzględnił rektorów uczelni oraz wybitnych nieżyjących profesorów. Wprowadzone zasady selekcji nie zyskały aprobaty recenzenta ${ }^{40}$. Krytyczna opinia oraz brak pełnej bibliografii toruńskiej uczelni spowodowały, że w drugim tomie Bibliografii miasta Torunia autor w pełniejszym wymiarze uwzględnił publikacje na temat UMK i jego pracowników.

Z kolei w Bibliografii Wilna H. Baranowski nie zamieścił opisów zawartych w zestawieniach odnoszących się do Uniwersytetu Wileńskiego. Uwzględnił jedynie pozycje wcześniej pominięte oraz wydane po ogłoszeniu bibliografii wileńskiej Almae Matris. Natomiast z bibliografii o Ostrej Bramie wybrał tylko 40 najważniejszych publikacji.

Przyjęte rozwiązanie należy uznać za jak najbardziej słuszne i uzasadnione. Zbyteczne jest bowiem powielanie pozycji, które wcześniej zostały zarejestrowane w odrębnych, często obszernych bibliografiach zagadnieniowych czy osobowych. Zainteresowany użytkownik może łatwo dotrzeć do poszukiwanych materiałów, a ich rejestracja sztucznie powiększyłaby objętość nowej bibliografii i obniżyłaby zarazem jej wartość użytkową.

${ }^{40}$ J. Kasprzyk, dz. cyt., s. 230-231. 


\section{Opis bibliograficzny}

Opis bibliograficzny pozycji w badanych bibliografiach cechuje się znacznym zróżnicowaniem. Różnorodność ta wynika nie tylko z rozmaitych form wydawniczych, piśmienniczych oraz typów zarejestrowanych dokumentów, ale także z innych względów. H. Baranowski na ogół starał się opisywać zgromadzone piśmiennictwo z autopsji. Jednak nie zawsze mógł dotrzeć do wszystkich dokumentów, stąd wzestawieniach oprócz opisów prymarnych znajdują się opisy pochodne,przejęte z innych źródeł informacji. Ich zapis dostosowany jest do zasad przyjętych w bibliografii. Autor stosował różne rodzaje opisu. Obok opisu rejestracyjnego pełnego, wprowadził opis skrócony oraz adnotowany. Publikacje napisane w alfabecie niełacińskim poddawał transliteracji. Troszczył się o dopasowanie zapisów poszczególnych typów dokumentów do norm obowiązujących w danym czasie. Na przestrzeni niemal sześćdziesięciu lat, kiedy ukazywały się omawiane bibliografie, normy zmieniały się kilka razy, co spowodowało modyfikacje w metodzie opisu uwzględnionych dokumentów. Wszystkie te czynniki sprawiły, że opisy są niejednolite, różnią się strukturą, szczegółowością danych, kolejnością elementów oraz formą zapisu.

We wszystkich bibliografiach na czele opisu znajduje się hasło. W przypadku druków autorskich funkcję tę pełni oryginalne nazwisko autora jego imię lub imiona, niekiedy inicjały imion. Zdarza się, że hasło autorskie stanowią pseudonimy i kryptonimy. Są one podawane w takiej postaci, w jakiej występują w tytulaturze dokumentu. H. Baranowski starał się rozwiązywać pseudonimy i kryptonimy, ustalać twórców dzieł anonimowych oraz przytaczać pełne imiona autorów. Jeśli identyfikacja powiodła się, to w haśle zamieszczał prawdziwe nazwisko autora dzieła, a bezpośrednio po nim podawał formę ukrytą. Wyjątkiem jest Bibliografia Wilna, w której kryptonimy i pseudonimy umieścił po tytule publikacji.

Również opis prac współautorskich zaczyna się od hasła. Jest nim nazwisko i imię pierwszego autora z tytulatury. Po nim znajdują się współautorzy, zgodnie z kolejnością ich występowania na karcie tytułowej.

Prace zbiorowe, wydawnictwa ciągłe oraz dzieła anonimowe o nieustalonym autorstwie są opisywane pod pierwszym wyrazem tytułu. Jeżeli na początku tytułu występują akronimy bądź liczebniki, to są one rozwiązywane. W celu ułatwienia percepcji bibliografii, nazwiska autorów 
oraz pierwsze wyrazy tytułów czasopism, prac redakcyjnych, edytorskich i publikacji o nieznanym autorstwie bibliograf wyróżnił wersalikami.

Jak już zostało powiedziane, H. Baranowski tworząc opisy bibliograficzne posiłkował się odpowiednimi normami, czego najlepszym przykładem jest pierwszy tom retrospektywnej Bibliografii miasta Torunia. W tym zestawieniu autor dostosował opis do obowiązujących wówczas polskich norm, tj.: PN-56/N-01156 Opis zasadniczy $w$ bibliografii retrospektywnej dziedzin i zagadnień, PN-65/N-01150 Skróty tytułów czasopism i wydawnictw zbiorowych i jej uzupełnienie PN-68/N-01178, choć sam przyznał, że w zapisie wprowadził „drobne odchylenia” ${ }^{41}$.

Opisując druki zwarte podawał kolejno: nazwę autora, tytuł, podtytuł (obydwa w pełnym brzmieniu), nazwy współpracowników (przy opisie prac zbiorowych, edytorskich, tłumaczeń itp.), części wydawnicze pojedynczych tomów lub całości dzieł wielotomowych (poprzedzone odpowiednim skrótem: „T.”, „Cz.”), tytuł tomu oraz nazwy współautorów, którzy je przygotowali, adres wydawniczy (miejsce wydania, nazwa instytucji wydawniczej /nie zawsze/, rok wydania), objętość, ilustracje, informacje o bibliografii załącznikowej, streszczeniach obcojęzycznych, nazwie instytucji sprawczej oraz serii wydawniczej wraz z jej numeracją. W przypadku braku tytułu, prace opisywał pod tytułem sfingowanym, po którym cytował początkowe wyrazu tekstu (incipit). Autor starał się ustalać brakujące elementy adresu wydawniczego, jeśli nie było ich w tytulaturze. Jeżeli to się nie udało, podawał stosowane w praktyce bibliograficznej skróty: „[B.m.]”, „[B.m.w.]”, „[B.r.]”, ,[B.m. i r.w.]”.

W opisie czasopism po tytule i podtytule wymieniał: częstotliwość (jeśli nie była określona w tytulaturze periodyku), nazwę instytucji wydawniczej bądź nakładcy, nazwę redaktora oraz miejsce wydania. Opis kończył numeracją periodyków, informując o pierwszym i ostatnim numerze czasopisma. W adnotacji umieszczał informacje o zmianach zachodzących w czasopiśmie na przestrzeni lat. Dotyczyło to przeważnie tytułu, nazwy redaktora oraz miejsca wydania.

Opis rozprawy z dzieła zbiorowego składał się z nazwy autora, tytułu i podtytułu publikacji, przyimka „W:”, cytaty wydawniczej, złożonej z tytułu pracy zbiorowej, miejsca i roku wydania, oraz objętości rozprawy i informacji o materiale ilustracyjnym.

${ }^{41}$ H. Baranowski, Przedmowa..., s. XIII. 
Analogiczną budowę ma opis artykułów z czasopism. Tutaj także po nazwie autora, tytule i podtytule artykułu bibliograf podawał cytatę wydawniczą, przy czym składa się ona z wyróżnionego kursywą tytułu czasopisma (z reguły w skrócie), rocznika/tomu (nie zawsze), roku wydania, numeru/zeszytu oraz stron artykułu. Opisy dopełniają informacje o ilustracjach i streszczeniach obcojęzycznych. Nieco inaczej cytata wydawnicza wygląda w opisie artykułów prasowych. Różnica polega na tym, że po numerze gazety przeważnie występuje data dzienna. Najczęściej nie ma też objętości artykułów.

Opis recenzji H. Baranowski podawał zawsze w adnotacji. Umieszczał ją bezpośrednio pod dziełem recenzowanym, przytaczanym w pełnym opisie rejestracyjnym. Zapis poprzedzał skrótem „Rec.:”, po którym wymieniał nazwę recenzenta (nazwisko i imię, pseudonim lub kryptonim), ewentualny tytuł recenzji oraz cytatę wydawniczą, zgodnie z zasadą przyjętą w opisie artykułów z czasopism.

W adnotacji zawarł również opis fragmentów. Analogicznie jak w przypadku recenzji, występuje on pod opisem rejestracyjnym publikacji, z której został zaczerpnięty. Na czele opisu podawał skrót „M.in.” bądź informował o jego objętości, a następnie wprowadzał zwięzłe określenie tematu. Zdarzało się, że zmieniał kolejność danych. Najpierw określał temat, a dopiero potem go lokalizował. W opisie fragmentów informował także o ilustracjach.

Opis rękopisów oraz niepublikowanych prac doktorskich i magisterskich ma postać skróconą. Zawiera on: nazwę autora, tytuł, miejsce i rok powstania, objętość oraz ilustracje. Ponadto w adnotacji określał formę dokumentu np. „Rękopis”, „Maszynopis”, informował o miejscu przechowywania danej pracy, przeważnie z podaniem sygnatury, i promotorach rozpraw doktorskich i prac magisterskich.

Również stare druki H. Baranowski opisywał w formie skróconej. Często wprowadzał skróty w zbyt długich tytułach publikacji, oznaczając wielokropkiem opuszczone fragmenty. $\mathrm{W}$ adresie wydawniczym pomijał nazwy nakładców, drukarzy i wydawców. Podawał natomiast miejsce i rok wydania, objętość oraz w adnotacji cytatę bibliograficzną.

Opis dokumentów kartograficznych i ikonograficznych niewiele różni się od opisu druków samoistnych zwartych. W opisie dokumentów kartograficznych po tytule występuje skala mapy bądź planu. Natomiast po adresie wydawniczym, w przypadku obu wymienionych typów do- 
kumentów, znajduje się informacja o technice graficznej, np. „Akwaf”, „Litogr., „Druk”, oraz format.

H. Baranowski nie pozostawał obojętny na zmiany przepisów normalizacyjnych w Polsce. Bardzo szybko reagował na wszelkie nowelizacje w tym zakresie oraz obserwował pod tym kątem praktykę bibliograficzną. Po wprowadzeniu przez „Przewodnik Bibliograficzny” w 1976 r. międzynarodowego znormalizowanego opisu bibliograficznego (ISBD), zmienił opis dzieł samoistnych zwartych w badanych bibliografiach. Nową postać opisu książek oraz niepublikowanych prac magisterskich wprowadził po raz pierwszy w bieżącej Bibliografii miasta Torunia, rejestrującej piśmiennictwo za lata 1975-1978. W kontynuacji tejże bibliografii, obejmującej lata 1979-1983, zmodyfikował także zasady opisywania rozpraw z dzieł zbiorowych, starych druków oraz samoistnie wydanych dokumentów kartograficznych i ikonograficznych, dostosowując je do normy: PN-82/N-01152.01 Opis bibliograficzny. Ksiq̨żki. Zgodnie z tą normą, opisywał wymienione jednostki bibliograficzne i rodzaje dokumentów w kolejnych częściach bieżącej i w drugim tomie retrospektywnej Bibliografii miasta Torunia oraz w Bibliografii Wilna. Do normy międzynarodowej dostosował również opis czasopism, z tym że uczynił to tylko w retrospektywnej bibliografii Torunia.

Opisy wzorowane na przepisach międzynarodowych tworzył z reguły w drugim stopniu szczegółowości. Konsekwentnie przestrzegał kolejności stref i poszczególnych elementów w ich obrębie. Respektował również, zalecany przez normę, cały system umownych znaków przestankowych i interpunkcyjnych oddzielających strefy i poszczególne składniki opisu. Zapis pozostałych jednostek bibliograficznych pozostawił w wymienionych bibliografiach bez większych zmian, czyli według „starej” normy bibliograficznej. W konsekwencji w jednym spisie występują dwa różne typy opisów, co może dezorientować użytkownika. Wydaje się, że lepszym rozwiązaniem było odłożenie terminu stosowania nowej normy dla książki i rozprawy z dzieła zbiorowego do momentu ukazania się normy opisu artykułów.

Oprócz opisu rejestracyjnego pełnego, H. Baranowski stosował także opis skrócony. Wykorzystywał go w głównej mierze do opisywania wznowień publikacji, kolejnych tomów dzieł wielotomowych, odbitek, nadbitek, przedruków, tłumaczeń oraz streszczeń. Identyfikacja tego typu prac nie nastręcza większych problemów. Są one zlokalizowane zazwyczaj w ad- 
notacji. Z reguły poprzedzają je odpowiednie skróty; „Przedr.”, „Odb.”, „Nadb.”, „Toż w jęz. ros.”, „Streszcz.”

W zapisie skróconym autor podawał tylko te elementy, które uległy zmianie. Pomijał natomiast powtarzające się składniki opisu, wprowadzając w zamian określniki znane z metodyki bibliograficznej. Tytuł publikacji zastępował wyrazem „Toż”, a miejsce wydania oraz tytuł czasopisma określeniem „tamże”. W bibliografiach Elbląga oraz Torunia, za wyjątkiem pierwszego tomu, nie powtarzał nazwy autora, jeśli była identyczna w kilku kolejnych pozycjach. Zamiast niej wprowadził poziome kreski ,- -", co odpowiadało nazwisku i imieniu autora. Natomiast w Bibliografii Wilna oraz w retrospektywnej Bibliografii miasta Torunia, opisując przedruki, zastępował powtarzającą się nazwę autora wyrazami „Jego", „Tenże”, „tegoż”, „tejże” lub „tychże”.

Opis rejestracyjny dopełniał w miarę potrzeby odpowiednimi adnotacjami księgoznawczymi i treściowymi, podnosząc tym samym wartość informacyjną bibliografii. W pierwszych informował nie tylko o fragmentach, recenzjach, odbitkach, przedrukach, tłumaczeniach, streszczeniach, wznowieniach czy lokalizacji prac niepublikowanych, o czym już wspomniano, ale też o cechach wydawniczo-formalnych dokumentu. Podawał wiadomości na temat autorstwa („Autor domniemany”, „Art. anonimowy”), adresu wydawniczego, języka publikacji („W jęz. hebr.”, „Tyt. i tekst również w jęz. lit.”), formy piśmienniczej („Wspomnienia”, „Przedm.., „Komentarz”, „Wiersz”, „Poemat”), techniki wykonania dokumentu („Maszyn. powiel.”, „Rękopis”, „Druk”) oraz przeznaczenia czytelniczego („Do użytku wew.”, „Do uż. wewn.-part.”). Ukazywał znaczenie społeczne i losy dokumentów („druk nielegalny”), informował o wysokości nakładu oraz określał objętość publikacji.

Spośród adnotacji treściowych H. Baranowski wykorzystywał najczęściej adnotacje wyjaśniające. Służyły one do zwięzłego objaśniania niejasnych tytułów. Wprowadził również adnotacje zawartościowe, które podawały pełny lub częściowy spis treści dokumentu (np. dzieł zbiorowych). Tego typu adnotacje poprzedzał, zgodnie z metodyką bibliograficzną, określeniami: „Treść” lub „Z treści”.

Adnotacje księgoznawcze i wyjaśniające lokalizował na trzy sposoby; podawał je bezpośrednio po tytule, na końcu opisu bądź pod opisem zasadniczym. W pierwszym przypadku dopowiedzenia są dodatkowo ujęte w nawias okrągły bądź prostokątny. Natomiast adnotacje zawartościowe 
zawsze umieszczał poniżej opisu rejestracyjnego. Są one wydrukowane mniejszym stopniem czcionki niż opis zasadniczy, co wpływa dodatnio na przejrzystość i czytelność bibliografii.

Pomimo dużego zróżnicowania, opisy bibliograficzne stworzone przez H. Baranowskiego dobrze spełniają swoją funkcję. Pozwalają na bezproblemową identyfikację zarejestrowanego piśmiennictwa.

\section{Uklad bibliografii}

Wybór rodzaju układu zrębu głównego w badanych bibliografiach był uzależniony od ilości zgromadzonego materiału. W najobszerniejszych spisach, tj. w bibliografiach Torunia, liczących w sumie 8204 pozycje oraz w Bibliografii Wilna, zestawiającej łącznie 10282 opisów, H. Baranowski wprowadził układ systematyczny. Jego budowę wzorował w znacznym stopniu na ramowym schemacie klasyfikacyjnym, opublikowanym w Metodyce bibliograficznej, opracowanym dla bibliografii regionalnych przedmiotowych ${ }^{42}$. Nie była to jednak wierna kopia. Dla każdej bibliografii autor wypracowywał indywidualną strukturę układu, biorąc pod uwagę specyfikę danego miasta. Jeśli zachodziła potrzeba, to modyfikował przygotowany schemat porządkowania materiału w kolejnych tomach poszczególnych zestawień.

Najbardziej rozbudowaną strukturę posiada Bibliografia Wilna. W drugim jej tomie zrąb główny dzieli się na dwadzieścia działów zasadniczych. Są to kolejno: „I. Dział ogólny”, „II. Prace ogólne”, „III. Środowisko geograficzno-przyrodnicze”, „IV. Dzieje miasta”, „V. Zagadnienia prawno-administracyjne”, „VI. Wojskowość”, „VII. Ludność”, „VIII. Zagadnienia społeczno-narodowościowe”, „IX. Wyznania”, „X. Zagadnienia gospodarcze”, „XI. Oświata”, „XII. Nauka”, „XIII. Kultura”, „XIV. Architektura i budownictwo”, „XV. Plastyka”, „XVI. Ochrona i konserwacja zabytków”, „XVII. Sport”, „XVIII. Życie codzienne”, „XIX. Wilno w literaturze, muzyce i filmie”, „XX. Osoby”. Poszczególne działy ulegają dalszemu podziałowi na jednostki niższego rzędu. Niekiedy podział sięga nawet czwartego stopnia. W trzecim tomie omawianej bibliografii autor zmniejszył liczbę

${ }^{42}$ B. Eychler, Bibliografia regionalna i lokalna..., s. 306-310. 
działów do dziewiętnastu. Ze względu na niewielką ilość materiału, nie uwzględnił działu „XVI. Ochrona i konserwacja zabytków”. Z tego samego powodu zrezygnował również z niektórych podziałów.

Inaczej natomiast postąpił z retrospektywną Bibliografiq miasta Torunia. Tutaj w drugim tomie powiększył liczbę działów głównych z czternastu do piętnastu. Odrębnym działem stały się „IX. Wyznania”, które w pierwszym tomie figurowały jako poddział pod nazwą „Sprawy wyznaniowe” w dziale „V. Sprawy społeczne i narodowe”. Wprowadził też kilka nowych poddziałów, niektórym zmienił nazwy, a część przeniósł do innych działów. Dzięki przeprowadzonym modyfikacjom, autor znacznie poprawił przejrzystość i użyteczność bibliografii.

Układ systematyczny jest niewątpliwie najlepszym sposobem porządkowania piśmiennictwa w bibliografiach lokalnych przedmiotowych, bowiem dostarcza wiadomości na temat wszystkich aspektów życia miasta. Pokazuje jednocześnie stan opracowania poszczególnych zagadnień, co pobudza i inspiruje do prowadzenia badań nad tematami jeszcze nie podjętymi.

Oprócz układu systematycznego, H. Baranowski stosował również układy formalne. Bibliografie Grudziądza i Elbląga wyposażył w układ alfabetyczny. Natomiast w bibliografii Słupska wprowadził układ według form wydawniczych i piśmienniczych. Autor z pewnością zdawał sobie sprawę $\mathrm{z}$ tego, że układy formalne nie są najlepszym sposobem porządkowania materiałów w bibliografii lokalnej przedmiotowej, ale zastosował je prawdopodobnie ze względu na niewielką ilość zgromadzonego piśmiennictwa.

Przy niedużej liczbie publikacji niecelowe jest oczywiście wprowadzanie układu rzeczowego o złożonej strukturze. H. Baranowski mógł jednak zastosować inny układ rzeczowy, np. działowy, który bardzo dobrze się sprawdza w bibliografiach o niewielkiej ilości materiału. Z punktu widzenia użytkownika bibliografii lokalnych przedmiotowych jest on bardziej korzystny niż układ alfabetyczny, bowiem dostarcza informacji na temat określonej problematyki, a więc tego, co najczęściej interesuje odbiorców badanych bibliografii.

Również szeregowanie wewnętrzne w badanych bibliografiach jest niejednolite. W pierwszym tomie Bibliografii miasta Torunia oraz w Bibliografii Wilna H. Baranowski zastosował szeregowanie według chronologii wydawniczej. Chciał w ten sposób pokazać rozwój piśmiennictwa 
poświęconego danemu zagadnieniu. W niektórych poddziałach łączył układ chronologiczny z logicznym, tzn. najpierw wymieniał prace o charakterze ogólnym, a potem bardziej szczegółowe ${ }^{43}$. W obrębie każdej z grup wprowadził porządek chronologiczny.

W bieżącej Bibliografii miasta Torunia oraz w drugim tomie tegoż zestawienia o charakterze retrospektywnym autor zrezygnował z szeregowania chronologicznego na rzecz alfabetycznego. Swoją decyzję motywował tym, że w bibliografii obejmującej niedługi okres - dwadzieścia lat - układ alfabetyczny jest bardziej celowy i wygodniejszy $\mathrm{w}$ korzystaniu ${ }^{44}$. Szeregowanie alfabetyczne występuje także wewnątrz grup formalnych w bibliografii Słupska.

Drugim rodzajem szeregowania wewnętrznego, występującym w każdej bibliografii Torunia i Wilna, było szeregowanie przedmiotowe. Autor wprowadzał je w różnych działach i poddziałach z reguły tam, gdzie uznał to za stosowne i możliwe do zrealizowania. Szeregowanie przedmiotowe występuje zawsze w dziale „Osoby” oraz w niektórych poddziałach, poświęconych m.in. stowarzyszeniom i organizacjom społecznym, zakładom pracy, szkołom, bibliotekom, muzeom, kościołom. Poprzez szeregowanie przedmiotowe dostarczał użytkownikom informacji na określony temat. Zwykle wyróżniał go graficznie przez spacjowanie bądź tłustym drukiem w tytule publikacji lub adnotacji.

Bibliografie o układzie systematycznym H. Baranowski wyposażył w liczne odsyłacze. Ich wprowadzenie zostało podyktowane jednokrotnym przydziałem pozycji do działów i poddziałów. Dzięki nim łączył pokrewne publikacje rozproszone w rozmaitych miejscach bibliografii. Najczęściej posługiwał się odsyłaczami numerowymi. Prowadziły one do numerów poszczególnych pozycji w obrębie danej bibliografii oraz kierowały do jej wcześniejszych tomów. Wykorzystywał także odsyłacze międzydziałowe beznumerowe, które wiodły do innych działów lub poddziałów.

Odsyłacze lokalizował z reguły na początku poszczególnych działów bądź poddziałów lub na ich końcu. Jedynym wyjątkiem były odsyłacze

43 A. Znajomski, Sprawność informacyjna bibliografii lokalnych wydanych $w$ Polsce w latach 1945-1989, [w:] A. Dymmel, S. D. Kotuła, A. Znajomski, Kultura czytelnicza i informacyjna - teoria i praktyka. Wybrane zagadnienia, Lublin 2015, s. 122.

${ }^{44}$ H. Baranowski, Wstęp, [w:] tenże, Bibliografia miasta Torunia..., s. XII. 
numerowe, kierujące do innych tomów bibliografii, które umiejscawiał zawsze pod opisem.

\section{Spisy pomocnicze}

Nie wszystkie badane bibliografie posiadają materiały informacyjno-pomocnicze. Legitymują się nimi tylko najobszerniejsze zestawienia, tj. bibliografie Torunia i Wilna. Wyposażono je w spis treści, oddający strukturę bibliografii, krótkie lub bardziej rozbudowane wprowadzenia, wstęp bądź przedmowę, przybliżające metodę opracowania oraz wykaz tytułów czasopism wraz z ich skrótami. Prócz tego w Bibliografii miasta Torunia występuje „Wykaz ważniejszych skrótów bibliograficznych”, zaś w Bibliografii Wilna znajduje się „Wykaz ważniejszych wykorzystanych źródeł", a w trzecim jej tomie, obok wstępu w języku polskim, jest także wstęp w języku litewskim.

Bibliografie Torunia i Wilna posiadają również „Skorowidze”, będące w rzeczywistości indeksami alfabetycznymi, ale uzupełnionymi o hasła osobowe. Zawierają one w jednym ciągu alfabetycznym nazwy autorów i współpracowników, tytuły dzieł zbiorowych i anonimowych, tytuły wydawnictw ciągłych oraz nazwiska osób występujących w tytułach publikacji lub adnotacjach. Są one przygotowane w sposób profesjonalny, przez co wydatnie podnoszą sprawność informacyjną bibliografii. Zgodnie z wymogami metodycznymi określają wkład autorów w przygotowanie publikacji (red., oprac., tłum., wyd., rec.), łączą odsyłaczami kryptonimy i pseudonimy z prawdziwymi nazwiskami autorów oraz kierują od drugiego członu nazwisk złożonych do ich formy dwuczłonowej. Dla ułatwienia poszukiwań $\mathrm{H}$. Baranowski wyróżnił kursywą tytuły czasopism oraz numery pozycji dotyczące osób, stanowiących przedmiot opisów. Wyjątkiem jest pierwszy tom Bibliografii miasta Torunia, w którym, zamiast numerów pozycji, graficznie wyróżnił hasła osobowe, ujmując je w nawias okrągły.

Niewielka objętość bibliografii Elbląga, Grudziądza i Słupska sprawiła, że autor nie wyposażył ich w żadne spisy pomocnicze. Choć nie posiadają one przedmów, wykazów skrótów oraz indeksów, to jednak użytkownik bez większego kłopotu może w nich odnaleźć i zidentyfikować potrzebne piśmiennictwo. 
Bibliografie lokalne autorstwa H. Branowskiego cechują się starannym przygotowaniem pod względem edytorskim. Dwuszpaltowy skład tekstu w zrębie głównym w większości bibliografii i indeksach, wcięcia akapitowe w poszczególnych pozycjach i odpowiednie interlinie między nimi, większy stopień czcionki w opisach zasadniczych, mniejszy zaś w opisach skróconych, adnotacjach i odsyłaczach, graficzne wyróżnienie haseł autorskich, przedmiotowych i tytułów czasopism w opisach bibliograficznych, odpowiednia interpunkcja oraz żywa pagina, wszystko to sprawia, że korzystanie z bibliografii jest łatwe i wygodne.

\section{Podsumowanie}

H. Baranowski tworzył bibliografie lokalne w sposób profesjonalny. Znając doskonale rzemiosło bibliograficzne, troszczył się o kompletność spisów, aczkolwiek, co warto podkreślić, eliminował publikacje o małej wartości. Wobec tego typu prac stosował selekcję merytoryczną. Stale doskonalił metodę opracowania bibliografii. Nowelizował opisy bibliograficzne, modyfikował sposób porządkowania materiału w zrębie głównym oraz w szeregowaniu wewnętrznym, udoskonalał indeksy. Dbał o stronę typograficzną swoich zestawień. Chciał w ten sposób stworzyć i dostarczyć odbiorcom jak najbardziej użyteczne i funkcjonalne źródła informacji. Prace H. Baranowskiego, a w szczególności Bibliografia miasta Torunia i Bibliografia Wilna, spotkały się z życzliwym przyjęciem przez krytyków nie tylko w Polsce, ale i za granicą. Recenzenci niejednokrotnie stawiali jego dzieła za wzór godny naśladowania. Poprzez działalność na polu badanych bibliografii, H. Baranowski zapewnił sobie trwałe i niepodważalne miejsce w dziejach polskiej bibliografii lokalnej.

\section{Bibliografia}

\section{Źródła}

Baranowski Henryk, Bibliografia historii Elblaga i regionu za lata 1945-1960, „Rocznik Elbląski” 1961, T. 1, s. 245-250.

Baranowski Henryk, Bibliografia historii Elblaga i regionu za rok 1961 wraz z uzupełnieniami od roku 1945, „Rocznik Elbląski” 1963, T. 2, s. 329-332. 
Baranowski Henryk, Bibliografia miasta Torunia, Warszawa 1972.

Baranowski Henryk, Bibliografia miasta Torunia. Materiały z lat 1972-1974 oraz uzupełnienia z lat poprzednich, „Rocznik Toruński” 1975, R. 10, s. 333-361.

Baranowski Henryk, Bibliografia miasta Torunia. Materiały z lat 1975-1978 wraz z uzupełnieniami z okresu wcześniejszego, „Rocznik Toruński” 1979, R. 14, s. 43-86.

Baranowski Henryk, Bibliografia miasta Torunia. Materiały z lat 1979-1983 wraz z uzupełnieniami z okresu wcześniejszego, „Rocznik Toruński” 1986, R. 17, s. 281-357.

Baranowski Henryk, Bibliografia miasta Torunia. Materiały z lat 1984-1989 wraz z uzupełnieniami z okresu wcześniejszego, „Rocznik Toruński” 1991, R. 20, s. 295-390.

Baranowski Henryk, Bibliografia miasta Torunia, t. 2, 1972-1993 wraz z uzupełnieniami, Toruń 1996.

Baranowski Henryk, Bibliografia [Słupska], [w:] Historia Słupska, red. Stanisław Gierszewski, Poznań 1981, s. 577-602.

Baranowski Henryk, Bibliografia Wilna, t. 2, Miasto, współpr. Zofia Baranowska, Jolanta Goławska, Toruń 2000.

Baranowski Henryk, Bibliografia Wilna, t. 3, Za lata 1999-2005 oraz uzupełnienia, współpr. Jolanta Goławska, Toruń 2007.

Baranowski Henryk, Przedmowa, [w:] Baranowski Henryk, Bibliografia miasta Torunia, Warszawa 1972, s. IX-XIII

Baranowski Henryk, Publikacje dotyczace Grudziądza i jego regionu w latach 1954-1959, „Rocznik Grudziądzki” 1960, T. 1, s. 313-315.

Baranowski Henryk, Wstęp, [w:] Baranowski Henryk, Bibliografia miasta Torunia, t. 2, 1972-1993 wraz z uzupełnieniami, Toruń 1996, s. XI-XII.

Baranowski Henryk, Wstęp, [w:] Baranowski Henryk, Bibliografia Wilna, t. 2, Miasto, współpr. Zofia Baranowska, Jolanta Goławska, Toruń 2000, s. XI-XIII.

Baranowski Henryk, Wstęp, [w:] Baranowski Henryk, Bibliografia Wilna, t. 3, Za lata 1999-2005 oraz uzupełnienia, współpr. Jolanta Goławska, Toruń 2007, s. XV-XVI.

Biedrzycki Adam, Bibliografia miasta Torunia za rok 2018 wraz z uzupełnieniami, „Rocznik Toruński” 2019, T. 46, s. 411-500.

Biedrzycki Adam, Szramowski Wojciech, Bibliografia historii Pomorza Wschodniego i Zachodniego oraz krajów regionu Bałtyku za rok 2015 wraz z uzupełnieniami z lat poprzednich, „Zapiski Historyczne” 2017, T. 82, suplement. 
Furmańska Katarzyna, Bibliografia grudziądzka za rok 2016, „Rocznik Grudziądzki" 2017, T. 25, s. 406-426.

Greczycho Krystyna, Bibliografia Elblaga za lata 2010-2015 wraz z uzupełnieniami z lat poprzednich, „Rocznik Elbląski” 2015, T. 26, s. 191-214.

Nędzewicz Maria, Bibliografia prac Henryka Baranowskiego za lata 1952-2000, [w:] Homo bibliographicus. Henryka Baranowskiego zmagania z bibliografia, Toruń 2001, s. 47-57.

\section{Opracowania}

Baranowski Henryk, Doktor Stefan Burhardt, „Głos Uczelni” 1980, nr 3-4, s. 47-50. Biskup Marian, Koncepcje i realizacja syntezy historii Torunia, „Rocznik Toruński” 1996, T. 23, s. 21-29.

Biskup Marian, Potrzeby historiograficzne Elblaga i jego regionu, „,Rocznik Elbląski" 1961, T. 1, s. 5-29.

Biskup Marian, Ze wspomnień o powstaniu i poczq̨tkach Rocznika Elbląskiego, „Rocznik Elbląski” 2006, T. 20, s. 15-20.

Borzyszkowski Józef, [Rec.], Baranowski Henryk, Bibliografia miasta Torunia, t. 2, 1972-1993 wraz z uzupetnieniami, Toruń 1996 „Pomerania” 1997, nr 6, s. 72.

Dubowik Henryk, Bibliografia Wilna - opus magnum Henryka Baranowskiego, [Rec.], Baranowski Henryk, Bibliografia Wilna, t. 2, Miasto, przy współpr. z Zofią Baranowską i Jolantą Goławską, Toruń 2000, „Wileńskie Rozmaitości" 2001, nr 2, s. 17.

Eychler Barbara, Bibliografia regionalna i lokalna, [w:] Metodyka bibliograficzna. Poradnik dla autorów bibliografii specjalnych, red. Helena Hleb-Koszańska, Maria Dembowska, Henryk Sawoniak, wyd. 2 zm., Warszawa 1963, s. 299-301.

Eychler Barbara, $Z$ problemów teoretycznych bibliografii regionalnych, „Przegląd Biblioteczny" 1971, R. 39, z.1-4, s. 141-149.

Heise Albert, [Rec.], Baranowski Henryk, Bibliografia miasta Torunia, Warszawa 1972, „Ostdeutscher Literatur-Anzeiger” 1973, Jg. 19, H. 3, s. 104-105.

Homo bibliographicus. Henryka Baranowskiego zmagania z bibliografia,Toruń 2001.

Jamiołkowski Andrzej, Henryk Baranowski - obywatel Wilna i Torunia, [w:] Baranowski Henryk, Bibliografia Wilna, t. 3, Za lata 1999-2005 oraz uzupełnienia, współpr. Jolanta Goławska, Toruń 2007, s. XI-XIII. 
Jarzębowski Leonard, Lisowski Stanisław, [w:] Słownik pracowników ksiażzi polskiej, Warszawa 1972, s. 521.

Jarzębowski Leonard, Lisowski Stanisław (1880-1964), [w:] Polski słownik biograficzny, t. 17, Wrocław 1972, s. 475-476.

Jaworska Janina, Z problematyki łódzkiej bibliografii regionalnej, „Kronika Miasta Łodzi" 1976, s. 115-129.

Kasprzyk Jerzy, [Rec.], Baranowski Henryk, Bibliografia miasta Torunia, Warszawa 1972, „Rocznik Kulturalny Kujaw i Pomorza” 1973/1974, T. 8, s. 230-231. Kazlauskienè D[anutè], Ž. Petrauskienè Ž[ibutè], Lenkijos mokslininko Vilniaus bibliografija, [Rec.], Baranowski Henryk, Bibliografia Wilna, t. 2, Miasto, przy współpr. z Zofią Baranowską, Jolantą Goławską, Toruń 2000, „Tarp Knygy" 2001, nr 6, s. 34-35.

Kosman Marceli, [Rec.], Baranowski Henryk, Bibliografia Wilna, t. 3, Za lata 1999-2005 oraz uzupełnienia, przy współpr. Jolanty Goławskiej, Toruń 2007, „Zapiski Historyczne” 2009, T. 74, z. 3, s. 141-143.

L[abuda] G[erard], [Rec.] Baranowski Henryk, Bibliografia miasta Torunia, Warszawa 1972, „Studia Źródłoznawcze” 1976, T. 20, s. 265-266.

Łowkis Sławomir, Uzupełnienia do Bibliografii Wilna, [Rec.], Baranowski Henryk, Bibliografia Wilna, t. 2, Miasto, przy współpr. z Zofią Baranowską, Jolantą Goławską, Toruń 2000, „Wileńskie Rozmaitości” 2002, nr 2, s. 11-12.

Maisel Witold, [Rec.], Baranowski Henryk, Bibliografia miasta Torunia, Warszawa 1972, „Zapiski Historyczne” 1974, T. 39, z. 1, s. 123-125.

Matczuk Alicja, [Rec.], Baranowski Henryk, Bibliografia miasta Torunia, t. 2, 1972-1993 wraz z uzupełnieniami, Toruń 1996, „Folia Bibliologica” 1996/1997, R. 44/45, s. 118-120.

Matczuk Alicja, Rozwój metodyczny polskich bibliografii historycznych regionalnych, Lublin 1994.

Myśliborski-Wołowski Stanisław, Polskie Towarzystwo Historyczne Oddział w Grudziądzu, „Rocznik Grudziądzki” 1960, T. [1], s. 295-299.

Od Redakcji, „Zapiski Historyczne” 1999, T. 64, suplement, s. [4].

Przybyszewski Kazimierz, Henryk Baranowski (1920-2011), bibliotekarz i bibliograf, „Rocznik Toruński” 2011, T. 38, s. 223-227.

Puciatowa Maria, Biblioteka Główna, [w:] Uniwersytet Mikołaja Kopernika 1945-1955, Warszawa 1957, s. 312-320.

Serczyk Jerzy, [Rec.] Baranowski Henryk, Bibliografia miasta Torunia, t. 2, 1972-1993 wraz z uzupełnieniami, Toruń 1996, „Rocznik Toruński” 1997, T. 24, s. $266-269$. 
Sierzputowski Włodzimierz, Powstanie i działalność Oddziału Polskiego Towarzystwa Historycznego w Elblagu w latach 1957-1960, „Rocznik Elbląski” 1961, T. 1, s. 227-232.

Supruniuk Anna, Supruniuk Mirosław A., Bibliotekarz i bibliograf. Pół wieku pracy dra Henryka Branowskiego na UMK, „Głos Uczelni” 1994, nr 1, s. 6. Supruniuk Anna, Supruniuk Mirosław A., O czym myśli bibliograf? Jubileusz dr. Henryka Baranowskiego, „Głos Uczelni” 2001, nr 3, s. 10.

Supruniuk Mirosław A., Pan Henryk, „Głos Uczelni” 2011, nr 3, s. 22.

(w), Odszedł wielki bibliograf, „Głos Uczelni” 2011, R. 10, nr 3, s. 23.

Wachowiak Bogdan, Henryka Baranowskiego Bibliografia historii Pomorza Wschodniego i Zachodniego oraz krajów regionu Battyku za lata 1959-1994 jej charakter i znaczenie, „Zapiski Historyczne” 1994, T. 59, z. 2-3, s. 7-12. Zaborska Urszula, Bibliografia historii Pomorza Wschodniego i Zachodniego oraz krajów regionu Bałtyku, „Bibliotekarz” 2018, nr 4, s. 8-14.

Zaborska Urszula, Doktor Henryk Baranowski (1920-2011), „Zapiski Historyczne” 2011, T. 76, z. 2, s. 163-170.

Zaborska Urszula, Starszy kustosz dyplomowany dr Henryk Baranowski (1920-2011), „Folia Toruniensia” 2011, T. 11, s. 173-175.

Znajomski Artur, Bibliografie lokalne w opinii krytyków, „Przegląd Biblioteczny” 2018, R. 86, z. 3, s. 374-391.

Znajomski Artur, Sprawność informacyjna bibliografii lokalnych wydanych w Polsce w latach 1945-1989, [w:] Dymmel Anna, Kotuła Sebastian Dawid, Znajomski Artur, Kultura czytelnicza i informacyjna - teoria i praktyka. Wybrane zagadnienia, Lublin 2015, s. 101-150.

\section{Henryk Baranowski (1920-2011) as an author of local bibliographies}

ABSTRACT: Henryk Baranowski contributed significantly to the development of the local bibliography in Poland. He wrote the retrospective bibliographies of Toruń, Wilno, and Słupsk, which pioneered and broke new ground for Polish works. He also initiated more current bibliographies of Elbląg and Grudziądz, which are continued to this day. Baranowski based his bibliographies on reliable sources. He strived for completeness in the selection of the material. And attached great importance to the proper preparation of the bibliography in terms of methodology. He used a standardized bibliographic description. If necessary 
and where appropriate, he introduced the short and annotated description. With great care, he applied factual and formal systems to organize the material which meant most of the completed bibliographies had a balance of appropriate information and supportive analysis. He also applied the same judicial attention to the editorial side of the lists. The local bibliographies created by Henryk Baranowski aroused great interest in the scientific world and were received positively.

KEYWORDS: Baranowski Henryk; local bibliography, history, methodology. 